\title{
Leaf breakdown in a natural open tropical stream
}

\author{
Elisa A.C.C. ALVIM,${ }^{1 *}$ Adriana O. MEDEIROS,${ }^{2}$ Renan S. REZENDE, ${ }^{1}$ José F. GONÇALVES JÚNIOR ${ }^{1}$ \\ ${ }^{1}$ AquaRiparia Program, Universidade de Brasília, Departamento de Ecologia, Campus Darcy Ribeiro, Asa Norte, 70.910-900, \\ Brasília, DF, Brazil; ${ }^{2}$ Universidade Federal da Bahia, Instituto de Biologia, Campus Universitário de Ondina, Ondina, 40.170-115, \\ Salvador, BA, Brazil \\ *Corresponding author: elisa.alvim@gmail.com
}

\begin{abstract}
Leaf breakdown is a primary process of nutrient cycling and energy flow, contributing to the functioning of aquatic ecosystems. In the present study, leaves of Baccharis platypoda and Coccoloba cereifera were incubated in a high-altitude stream in a rupestrian field. Two hypotheses were tested: $i$ ) intrinsic factors (quality of detritus) are more important than extrinsic factors (decomposer communities) in decomposition; and ii) low detritus quality hinders microbial colonization, thereby altering the composition and structure of the associated invertebrate community and slowing leaf breakdown. The breakdown coefficients of $\mathrm{B}$. platypoda and C. cereifera leaves were low $\left(k=-0.0019 \mathrm{day}^{-1}\right.$ and $k=-0.0008 \mathrm{day}^{-1}$, respectively) and the proportions of structural compounds were high, delaying the remobilization of energy and nutrients into the aquatic ecosystem. Fungal biomass was higher at the end of the experiment, suggesting favorable conditions for colonization. The densities of invertebrates associated with the detritus increased coincident with the peak concentration of ergosterol, with the trophic groups collector-gatherer and scraper having the highest densities. The distribution of these groups was likely related to the growth of biofilm on the surface of the litters. As described for tropical streams, shredders had the lowest densities of any invertebrate group, suggesting a reduced participation of these invertebrates in leaf processing. The results suggest that slow decomposing species are important to both invertebrates and microorganisms as substrates and sources of particulate organic matter. The low palatability and nutritional quality of the detritus in the present study, associated with low dissolved nutrient concentrations in water, delayed the leaf conditioning process by microorganisms. Decomposition rates and invertebrate participation were reduced as a result, leading to major physical decomposition. Headwater tropical streams have chemically diverse detrital resources, and the intrinsic factors of litter may play key roles in the decomposition process.
\end{abstract}

Key words: Invertebrates, litter decomposition, microorganisms, rupestrian field, secondary compounds.

Received: March 2014. Accepted: September 2014.

\section{INTRODUCTION}

Allochthonous organic matter is one of the main food resources in headwater streams ( $1{ }^{\text {st }}-3^{\text {rd }}$ order $)$, and its availability is directly related to the presence of well-developed riparian vegetation (Vannote et al., 1980). The leaf breakdown rate may be influenced by i) extrinsic aquatic environmental characteristics, such as temperature, flow, water chemistry and the presence of decomposing organisms (Chara et al., 2007); and ii) intrinsic factors of the litter that determine decomposition rates, including nutrient content (Flindt and Lillebø, 2005) and concentrations of chemical defense compounds (e.g., polyphenols and tannins) (Graça and Bärlocher, 2005) and structural compounds, such as lignin and cellulose (Ardón et al., 2006).

Leaf litter decay and the chemical transformation of the soluble compounds of litter in streams result from leaching, physical abrasion, microbial and invertebrate colonization and fragmentation (Gessner et al., 1999; Das et al., 2008). At least three biological communities (fungal, bacterial and invertebrate) are involved in the biological transformation of this organic matter (Hieber and Gessner, 2002). Fungi play a primary role in this process due to their ability to metabolize molecules that do not readily degrade (e.g., cellulose and lignin) (Gessner et al., 1999). These microorganisms also increase the nutritional quality of decomposing litter and enhance its palatability to invertebrate consumers (Canhoto and Graça, 1999).

Within the macrodecomposer community, invertebrate shredders are more commonly found in low-order streams with dense canopies (Vannote et al., 1980; Wallace and Eggert, 2009). As they directly consume leaf tissue, they play an important role in the conversion of coarse particulate organic matter into fine and dissolved particulate organic matter (Cummins et al., 1989; Encalada et al., 2010). However, in tropical streams, shredders have low abundance and richness (Gonçalves et al., 2006a; Moretti et al., 2007).

In tropical high-altitude savanna systems, the adverse environmental conditions (low temperatures and humidity) favor plant species with thick cuticles and high concentrations of structural and inhibitory compounds in their leaves (Wantzen et al., 2005). These environmental conditions might also decrease the metabolism and consequently the activity of decomposer communities. We hypothesized that: i) intrinsic factors (specifically, the quality of detritus) are 
more important than extrinsic factors (specifically, decomposer communities) in leaf breakdown; and that ii) low detritus quality hinders microbial colonization, thereby altering the composition and structure of the associated invertebrate community and decreasing the rate of leaf breakdown. In contrast, detritus is an appropriate substrate for biofilm, particularly in streams in open canopy forest with high light incidence, encouraging primary production. Initially, detritus might serve as a substrate, but slow colonization by fungi over time will lead to the decomposition of hard detritus compounds, inputting energy and nutrients into the system. This integration of ecosystem processes (decomposition and primary production) could be responsible for the high productivity in Cerrado streams, where decomposers and biofilm merge in a unique food web. Therefore, the objective of this study was to investigate the influences of stream chemical composition, invertebrate communities and microorganisms on the litter decomposition of Baccharis platypoda DC. (Asteraceae) and Coccoloba cereifera Schwacke (Polygonaceae) in a high-altitude tropical stream in Brazil, where those species are widely distributed.

\section{METHODS}

\section{Study site}

This study was conducted in a 2nd-order stream (Geraldinho Stream) in Serra do Cipó, Minas Gerais, Brazil, within the São Francisco Basin (19¹6'55.51'S, $43^{\circ} 35^{\prime} 34.46^{\prime \prime} \mathrm{W}$; altitude $1135 \mathrm{~m}$ ). The riparian zone is composed of bushes and grasses in rupestrian fields and does not form a true canopy over the water body. The experiment was carried out in the dry season between May and September 2009. The mean annual temperature in the region varies between 17.0 and $18.5^{\circ} \mathrm{C}$, and the mean annual precipitation varies between 1450 and $1800 \mathrm{~mm}$ (Gonçalves et al., 2006a).

\section{Experimental procedure}

Senescent leaves of Baccharis platypoda and Coccoloba cereifera were collected of various individuals around the stream studied with nets in order to avoid contact with the soil. These species are widely distributed in the study area, and C. cereifera is endemic to the rupestrian fields of Serra do Cipó. Leaves of each species were separately and placed in litter bags $(10 \mathrm{~mm}$ mesh), with $1.5 \pm 0.1 \mathrm{~g}$ of air-dry weight of $B$. platypoda and $3.5 \pm 0.5 \mathrm{~g}$ of $C$. cereifera per bag. Sixty-four litter bags were incubated horizontally in the stream bed, tied to steel rods and stones, similar to natural conditions.

During each sampling period, we measured current speed with a fluxometer (model SWOFFER 2100 series), water temperature (Oximeter YSI 55), dissolved oxygen (Oximeter YSI 55), pH (Digimed MD 20), and electrical conductivity (Minipa MCD-2000) with field meters. One liter of water was collected during each period for total alkalinity analysis and nutrient measurements. Total alkalinity was measured using the Gran method (Carmouze, 1994), nitrate and orthophosphate concentrations were measured as outlined in Standard Methods for the Examination of Water and Wastewater, soluble reactive phosphorus was measured using the ascorbic acid method and nitrate concentration was measured using the cadmium column reduction method (APHA, 2005).

Decomposition rates were measured as the reduction in leaf litter weight over the 120 days of incubation (with partial retrieval of leaves on days $3,7,15,21,30,60,90$, and 120). On each sampling date, four litter bags of each species were removed, placed in individual plastic bags and transported to the laboratory inside containers with ice. In addition to the 64 litter bags, we prepared four replicates of each species, corresponding to day zero. The litter from day zero was used to evaluate mass reductions arising from the preparation, handling and transportation of samples in the field, thus allowing corrections for losses not attributed to decomposition. These samples were also used to determine the initial characterization of the litter with respect to the concentrations of secondary and structural compounds. To estimate the percentage of water in the leaves, a linear regression of air-dry weight and oven-dry weight $\left(60^{\circ} \mathrm{C}, 72 \mathrm{~h}\right)$ was performed.

In the laboratory, the leaves were gently washed in distilled water over a $120-\mu \mathrm{m}$ sieve to remove sediment and retain the invertebrates. After washing, five leaves were selected from each litter bag, and four discs were cut from each leaf using a cork borer (diameter $12 \mathrm{~mm}$ ), yielding four sets of five discs from each bag. These sets were used to measure the ash-free dry mass (AFDM), the concentration of the total microbial biomass (ATP), the concentration of fungal biomass (ergosterol) and the fungal sporulation rate. The remainder of the material was oven-dried at $60^{\circ} \mathrm{C}$ for $72 \mathrm{~h}$, and its dry weight was measured before being ground down for analyses of chemical composition.

\section{Leaf characteristics}

The concentration of total polyphenols was measured following Bärlocher and Graça (2005). The content of condensed tannins was estimated according to Graça and Bärlocher (2005). Gravimetric analysis, which measures the quantity of a compound within a sample, was used to measure the cellulose and lignin contents (Gessner, 2005a).

\section{Microorganisms}

The total biomass of microorganisms was measured by quantifying the ATP in the litter as proposed by Abelho (2005). The biomass of the aquatic fungi in the decomposing leaves was analyzed by quantifying the ergosterol content, exclusive lipid in the fungal membrane (Gessner, 
$2005 \mathrm{~b})$. The reproductive rate of the aquatic hyphomycetes was calculated from spore counts. One set of five discs was incubated for $48 \mathrm{~h}$ at $19^{\circ} \mathrm{C}$ in an Erlenmeyer flask containing $30 \mathrm{~mL}$ of filtered stream water for sporulation induction using an orbital shaker. The conidial suspension was transferred to a flask and fixed with $2 \mathrm{~mL}$ of $37 \%$ formaldehyde for subsequent spore counts and identification. To prepare the slides, triton X - 100 (30 $\mu \mathrm{L}$ of $15 \%$ ) was added to avoid conidial adherence to the flasks. An aliquot of the suspension was then filtered, and the filter was stained with $0.05 \%$ cotton blue in lactic acid (60\%) (Bärlocher, 2005).

\section{Invertebrate assemblages}

The material retained by the $120-\mu \mathrm{m}$ sieve was preserved in ethanol $70 \%$. The invertebrates were then sorted and identified to the family level using the following identification keys: Merrit and Cummins (1996) and Mugnai et al. (2009). The organisms found were classified into the following functional feeding categories: collectors-gatherers, collectors-filterers, scrapers, predators and shredders (Cummins et al., 2005). The richness, density and composition of the invertebrate community were also determined.

\section{Data analysis}

The coefficients of decomposition were calculated by adjusting the mass loss percentage data according to the negative exponential model $\mathrm{Wt}=\mathrm{W}_{\mathrm{o}} \mathrm{e}^{-\mathrm{kt}}$, where $\mathrm{Wt}$ is the weight remaining at time $t$ (in days), $\mathrm{W}_{\mathrm{o}}$ is the initial mass, and $k$ is the coefficient of decomposition (Olson, 1973).

To analyze the variation in mass loss in the microbial community and the variation in the chemical characteristics of the litter between the two species studied over the incubation time, generalized linear models (GLM) were constructed and adjusted to a normal error distribution (function $\mathrm{glm}$, package stats for R). The models were subjected to residual analysis to verify model compliance with the chosen error distribution (package RRJ for R). GLMs were used to analyze the influences of sampling period, litter type and their interaction on the richness and density of aquatic invertebrates. A PerMANOVA was used to analyze the effects of litter type, incubation time and their interaction on the functional trophic groups of the invertebrate community. For the latter analysis, we used the Bray-Curtis distance with 10000 permutations and a pseudo-F statistic (function Adonis, package vegan for R). The analyses were carried out using R v2.6.2 software (R Development Core Team, 2008).

\section{RESULTS}

\section{Physical and chemical characteristics of the stream}

The following water parameter measurements were obtained: average temperature, $21.0 \pm 0.5^{\circ} \mathrm{C}$; electrical conductivity, 59.6 $\pm 16.9 \mu \mathrm{S} \mathrm{cm}^{-1} ; \mathrm{pH}, 7.0 \pm 0.3$; dissolved oxygen content, $8.1 \pm 0.2 \mathrm{mg} \mathrm{L}^{-1}$; alkalinity, $12.5 \pm 3.9 \mathrm{mEq} \mathrm{L}^{-1}$; water velocity, $0.06 \pm 0.009 \mathrm{~m} \mathrm{~s}^{-1}$; and flow rate, $0.003 \pm 0.001 \mathrm{~m}^{3}$ $\mathrm{s}^{-1}$. The concentrations of ortophosphate and nitrate were below the detection limits of the methodology used (nitrate: $<0.10 \mathrm{mg} \mathrm{L}^{-1} \mathrm{~N}$; orthophosphate: $<0.015 \mathrm{mg} \mathrm{L}^{-1} \mathrm{P}$ ).

\section{Leaf breakdown}

During the first seven days of incubation, rapid weight loss was observed for B. platypoda leaves, with a slower rate of loss for C. cereifera (Fig. 1). These rates were significantly different between the two species and among incubation times; however, there was no significant effect of the species-by-time interaction (Tab. 1). After 120 days, B. platypoda had $77.2 \%$ of its original weight remaining, and C. cereifera had $88.1 \%$.

The coefficient of decomposition was higher for $B$. platypoda $\left(k=-0.0019\right.$ day $\left.^{-1}\right)$ than for $C$. cereifera $(k=$ 0.0008 day $\left.^{-1}\right)$. To reach $50 \%$ decomposition of mass, 495 days would be necessary for B. platypoda litter and 866 days for $C$. cereifera litter.

\section{Chemical characteristics of detritus}

The concentrations of total polyphenols and condensed tannins did not differ significantly between the two species or among incubation times, nor was there a significant species-by-time interaction (Tab. 1). The initial contents of secondary compounds, i.e., total polyphenols and condensed tannins, were $22.5 \pm 5.7 \%$ and $1.7 \pm 0.4 \%$, respectively, for B. platypoda and $28.1 \pm 6.7 \%$ and $2.9 \pm 0.01 \%$, respectively, for $C$. cereifera. After fifteen days of incubation, the total polyphenols loss was estimated as $23 \%$ for B. platypoda and $45 \%$ for C. cereifera. In contrast, the loss

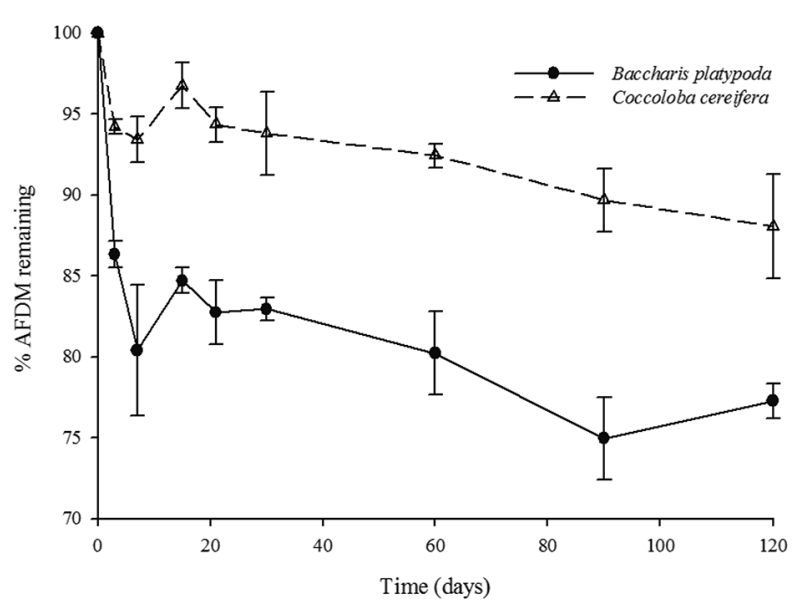

Fig. 1. Mass loss (mean \% and standard error) of Baccharis platypoda and Coccoloba cereifera leaves due to breakdown in Geraldinho stream. 
of condensed tannins at this time was $15 \%$ for B. platypoda and $47 \%$ for $C$. cereifera (Fig. 2 A,B).

There were significant differences between the two species in the concentrations of structural compounds (Tab. 1). Baccharis platypoda presented lower initial concentrations of cellulose $(29.1 \pm 0.3 \%)$ and lignin $(22.5 \pm 2.7 \%)$ than C. cereifera $(44.3 \pm 3.8 \%$ and $42.7 \pm 0.5 \%$, respectively; Fig. 2 C,D). After 120 days, the percentages of cellulose and of lignin in B. platypoda were higher than their initial values. In contrast, the percent of cellulose decreased and the percent of lignin increased in C. cereifera over time (Fig. 2 C,D). No significant interaction of species and time was observed (Tab. 1).

\section{Total microbial biomass}

The concentration of ATP in the litter differed significantly between species and among incubation times, and

Tab. 1. Generalized linear models to evaluate whether the mass loss, the microbial and invertebrate community and the chemical characteristics of detritus varied between the species studied, as a function of incubation time.

\begin{tabular}{|c|c|c|c|c|c|c|c|}
\hline Response variable & $\begin{array}{l}\text { Explanatory } \\
\text { variable }\end{array}$ & DF & Deviance & Residual DF & $\begin{array}{l}\text { Residual } \\
\text { deviance }\end{array}$ & F & $P$ \\
\hline Mass loss & $\begin{array}{l}\text { Null model } \\
\text { Detritus } \\
\text { Time } \\
\text { Detritus x Time }\end{array}$ & $\begin{array}{l}1 \\
8 \\
8\end{array}$ & $\begin{array}{c}2010 \\
1199 \\
201\end{array}$ & $\begin{array}{l}66 \\
65 \\
57 \\
49\end{array}$ & $\begin{array}{c}4054 \\
2043 \\
843 \\
642\end{array}$ & $\begin{array}{c}153.4 \\
11.4 \\
1.9\end{array}$ & $\begin{array}{c}<0.001 \\
<0.001 \\
0.077\end{array}$ \\
\hline Total polyphenols & $\begin{array}{l}\text { Null model } \\
\text { Detritus } \\
\text { Time } \\
\text { Detritus x Time }\end{array}$ & $\begin{array}{l}1 \\
8 \\
8\end{array}$ & $\begin{array}{l}0.1 \\
984 \\
365\end{array}$ & $\begin{array}{l}58 \\
57 \\
49 \\
41\end{array}$ & $\begin{array}{l}4121 \\
4121 \\
3136 \\
2771\end{array}$ & $\begin{array}{c}0.001 \\
1.8 \\
0.6\end{array}$ & $\begin{array}{l}0.971 \\
0.100 \\
0.709\end{array}$ \\
\hline Condensed tannins & $\begin{array}{l}\text { Null model } \\
\text { Detritus } \\
\text { Time } \\
\text { Detritus x Time }\end{array}$ & $\begin{array}{l}1 \\
8 \\
8\end{array}$ & $\begin{array}{c} \\
6.1 \\
23.1 \\
12.2\end{array}$ & $\begin{array}{l}57 \\
56 \\
48 \\
40\end{array}$ & $\begin{array}{c}102.9 \\
96.9 \\
73.8 \\
61.6\end{array}$ & $\begin{array}{l}3.9 \\
1.9 \\
0.9\end{array}$ & $\begin{array}{l}0.055 \\
0.091 \\
0.457\end{array}$ \\
\hline Cellulose & $\begin{array}{l}\text { Null model } \\
\text { Detritus } \\
\text { Time } \\
\text { Detritus x Time }\end{array}$ & $\begin{array}{l}1 \\
8 \\
8\end{array}$ & $\begin{array}{c}781 \\
45 \\
132 \\
\end{array}$ & $\begin{array}{l}46 \\
45 \\
37 \\
29\end{array}$ & $\begin{array}{l}1688 \\
906 \\
861 \\
729\end{array}$ & $\begin{array}{c}31.1 \\
0.2 \\
0.6\end{array}$ & $\begin{array}{c}<0.001 \\
0.983 \\
0.723\end{array}$ \\
\hline Lignin & $\begin{array}{l}\text { Null model } \\
\text { Detritus } \\
\text { Time } \\
\text { Detritus x Time }\end{array}$ & $\begin{array}{l}1 \\
8 \\
8\end{array}$ & $\begin{array}{c}8263 \\
500 \\
177\end{array}$ & $\begin{array}{l}46 \\
45 \\
37 \\
29\end{array}$ & $\begin{array}{c}9524 \\
1,260 \\
759 \\
581\end{array}$ & $\begin{array}{c}411.9 \\
3.1 \\
1.1\end{array}$ & $\begin{array}{c}<0.001 \\
0.011 \\
0.386\end{array}$ \\
\hline ATP & $\begin{array}{l}\text { Null model } \\
\text { Detritus } \\
\text { Time } \\
\text { Detritus x Time }\end{array}$ & $\begin{array}{l}1 \\
7 \\
7\end{array}$ & $\begin{array}{c}182 \\
1429 \\
1401\end{array}$ & $\begin{array}{l}57 \\
56 \\
49 \\
42\end{array}$ & $\begin{array}{l}4560 \\
4377 \\
2948 \\
1546\end{array}$ & $\begin{array}{l}4.9 \\
5.5 \\
5.4\end{array}$ & $\begin{array}{c}0.031 \\
<0.001 \\
<0.001\end{array}$ \\
\hline Ergosterol & $\begin{array}{l}\text { Null model } \\
\text { Detritus } \\
\text { Time } \\
\text { Detritus x Time }\end{array}$ & $\begin{array}{l}1 \\
8 \\
7\end{array}$ & $\begin{array}{c}8514 \\
299,628 \\
347,954\end{array}$ & $\begin{array}{l}54 \\
53 \\
45 \\
38\end{array}$ & $\begin{array}{c}1,067,682 \\
1,059,167 \\
759,539 \\
411,585\end{array}$ & $\begin{array}{l}0.8 \\
3.4 \\
4.6\end{array}$ & $\begin{array}{c}0.380 \\
0.004 \\
<0.001\end{array}$ \\
\hline Sporulation & $\begin{array}{l}\text { Null model } \\
\text { Detritus } \\
\text { Time } \\
\text { Detritus x Time }\end{array}$ & $\begin{array}{l}1 \\
7 \\
7\end{array}$ & $\begin{array}{l}21.8 \\
15.1 \\
11.5\end{array}$ & $\begin{array}{l}57 \\
56 \\
49 \\
42\end{array}$ & $\begin{array}{c}127.9 \\
106.1 \\
90.9 \\
79.4\end{array}$ & $\begin{array}{c}11.5 \\
1.1 \\
0.8\end{array}$ & $\begin{array}{c}<0.001 \\
0.356 \\
0.536\end{array}$ \\
\hline Density invertebrate & $\begin{array}{l}\text { Null model } \\
\text { Detritus } \\
\text { Time } \\
\text { Detritus x Time }\end{array}$ & $\begin{array}{l}1 \\
7 \\
7\end{array}$ & $\begin{array}{l}3017.2 \\
6249.8 \\
2594.0\end{array}$ & $\begin{array}{l}59 \\
58 \\
51 \\
44\end{array}$ & $\begin{array}{c}15,988 \\
12,970.7 \\
6721.0 \\
4127.0\end{array}$ & $\begin{array}{c}32.2 \\
9.5 \\
3.9\end{array}$ & $\begin{array}{c}<0.001 \\
<0.001 \\
0.001\end{array}$ \\
\hline Richness invertebrate & $\begin{array}{l}\text { Null model } \\
\text { Detritus } \\
\text { Time } \\
\text { Detritus x Time }\end{array}$ & $\begin{array}{l}1 \\
7 \\
7\end{array}$ & $\begin{array}{c}0.001 \\
6.8 \\
5.4\end{array}$ & $\begin{array}{l}59 \\
58 \\
51 \\
44\end{array}$ & $\begin{array}{l}48.7 \\
48.7 \\
41.9 \\
36.4\end{array}$ & & $\begin{array}{l}0.976 \\
0.452 \\
0.604\end{array}$ \\
\hline
\end{tabular}

DF, degrees of freedom; ATP, total microbial biomass. 
there was a significant interaction of species and time (Tab. 1). In B. platypoda, the ATP content was higher during the final stage of decomposition (1235.5 \pm 337.4 nmoles $\mathrm{g}^{-1}$ ). In $C$. cereifera, the highest value was observed during the initial stage of the process, reaching $3315.4 \pm 1080.1$ nmoles g $^{-1}$ (Fig. 3A).

\section{Fungal colonization}

Initial ergosterol concentrations were $278.1 \mu \mathrm{g} \mathrm{g}^{-1}$ AFDM for B. platypoda litter and $91.2 \mu \mathrm{g} \mathrm{g}^{-1}$ AFDM for $C$. cereifera litter. The concentration of ergosterol did not differ between the species in relation to time, but there was significant difference between the incubation times
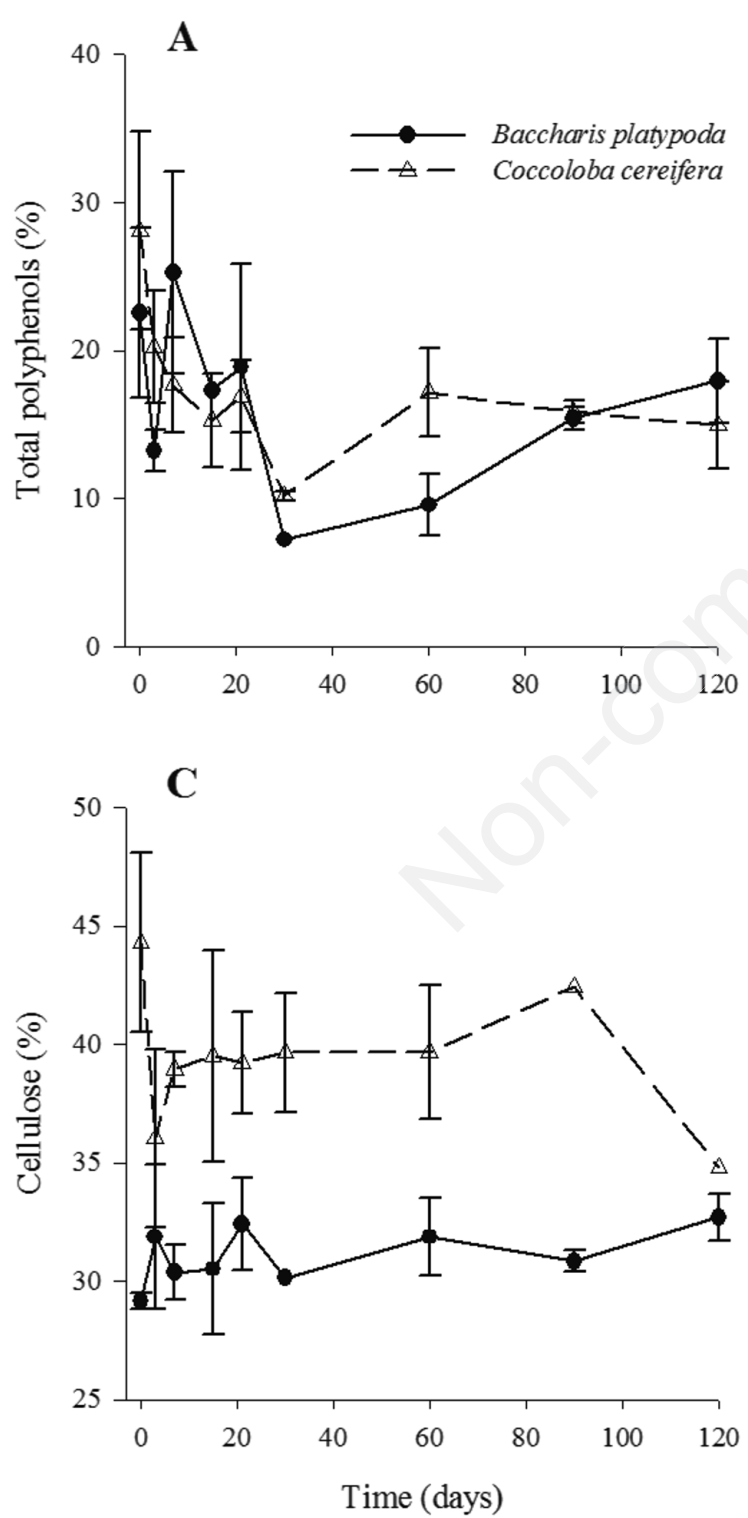

(Tab. 1). After the incubation, we observed a reduction in the concentration of ergosterol for B. platypoda detritus. The biomass of fungal associated to the decomposing leaves remained stable, reaching the highest values at $120^{\text {th }}$ day of incubation for both detritus (B. platypoda $=270.1 \pm 31.4 \mu \mathrm{g} \mathrm{g}^{-1} \mathrm{AFDM}$ and C. cereifer $a=183.0$ $\pm 38.9 \mu \mathrm{g} \mathrm{g}^{-1}$ AFDM; Fig. 3B).

The peak of sporulation of the aquatic hyphomycetes occurred on day 30 in B. platypoda (3.4 spores $\mathrm{mg}$ $\mathrm{AFDM}^{-1}$ ), while sporulation rates did not vary over time in C. cereifera (Fig. 3C). Spore numbers differed significantly between the two litter types but not among incubation times (Tab. 1).
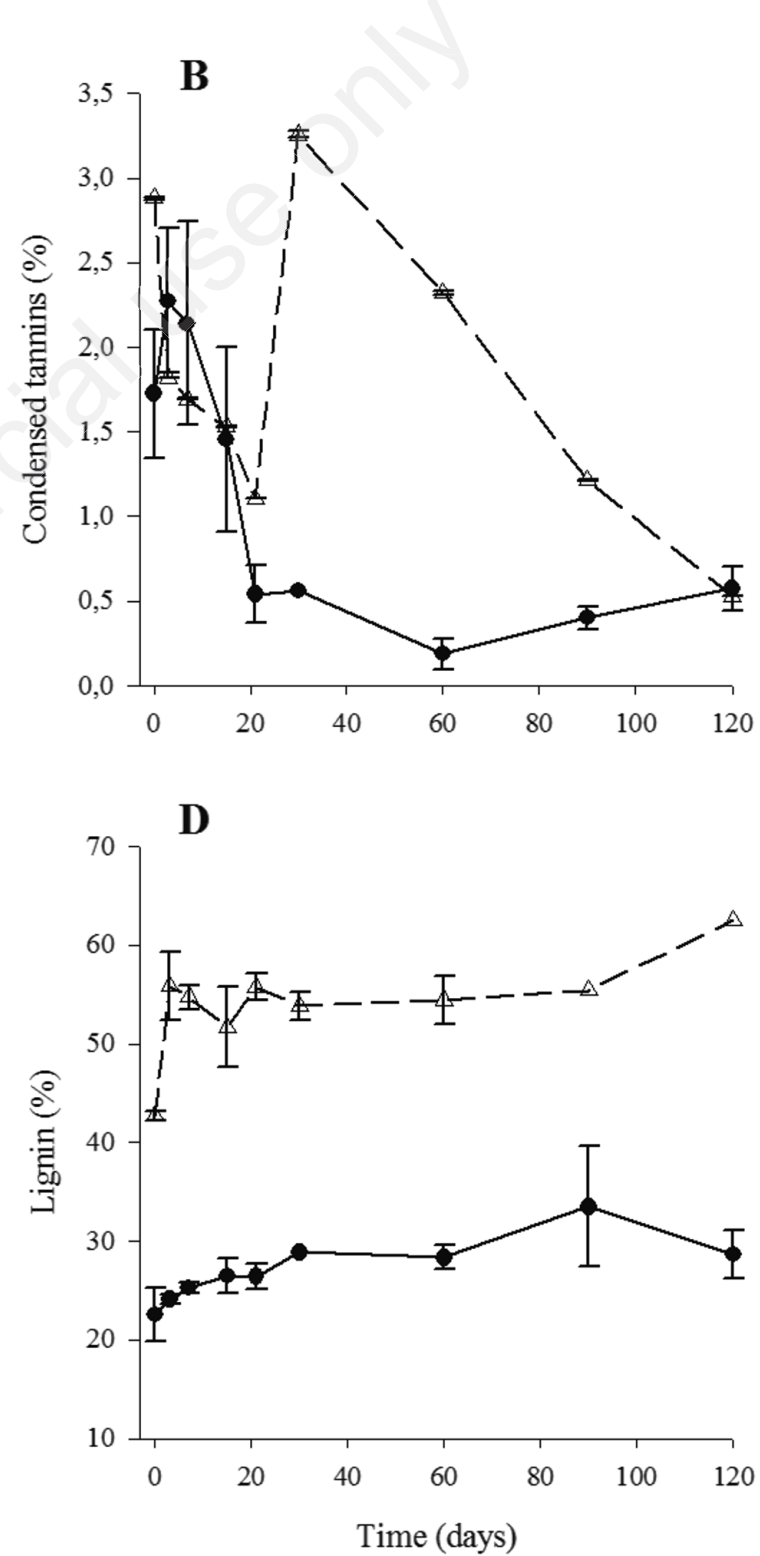

Fig. 2. Changes in the concentrations of secondary and structural compounds (mean \% and standard error) in decomposing leaves of Baccharis platypoda and Coccoloba cereifera in Geraldinho Stream. A) Total polyphenols; B) condensed tannins; C) cellulose; D) lignin. 


\section{Invertebrate associated to detritus}

The densities of invertebrates associated with the litter were low during the first days of incubation (Fig. 4A). Baccharis platypoda presented higher density values from the $60^{\text {th }}$ day of incubation onward, reaching 42.8 ind $\mathrm{g}^{-1}$ AFDM after 120 days. In contrast, $C$. cereifera presented higher values from the $90^{\text {th }}$ day onward, reaching 19.5 ind $\mathrm{g}^{-1}$ AFDM at the end of the $120^{\text {th }}$ day. The total density values different significantly between litter types and among incubation times, and there was a significant species-by-time interaction (Tab. 1).

The taxonomic richness of invertebrates increased over the first days of incubation; however, no significant differences were observed between litter types or among incubation times, nor was there a significant species-bytime interaction (Fig. 4B; Tab. 1). The structure of the invertebrate community was similar between the two species, composed predominantly of members of the Chironomidae (Diptera), Baetidae (Ephemeroptera) and Hydroscaphidae (Coleoptera). These three taxa represented more than $90 \%$ of the total number of organisms found in B. platypoda and C. cereifera litter, with Chironomidae larvae comprising $70.9 \%$ and $62.1 \%$, respectively (Supplementary Tabs. 1 and 2).

The functional feeding groups of the invertebrate community differed significantly between species and among incubation times; their interaction was also significant (Tab. 2). The density of trophic group collectors-gatherers was significantly different between litters and among incubation times (Tab. 2), showing the highest values between the $15^{\text {th }}$ and $30^{\text {th }}$ days of incubation in B. platypoda $(65-86 \%)$ and between the $7^{\text {th }}$ and $30^{\text {th }}$ days in $C$. cereifera (72-95\%) (Fig. 5). The density of scrapers also differed significantly between litters and among incubation times (Tab. 2), showing higher densities during the initial and final stages in $B$. platypoda and from the $60^{\text {th }}$ day onward in $C$. cereifera (52-74\%) (Fig. 5). Shredders had the lowest densities of any group in both B. platypoda and $C$. cereifera $(0.5 \%$ and $1.7 \%$, respectively), with no significant differences between litters or among incubation times (Tab. 2). Predators also presented no significant differences (Tab. 2), with the highest densities observed in B. platypoda (Fig. 5A). The density of collectors-filterers only differed significantly among incubation times (Tab. 2).

\section{DISCUSSION}

\section{Decomposition rates and chemical quality of detritus}

The coefficients of decomposition for Baccharis platypoda and Coccoloba cereifera are low $(k<-0.0041$ $\left.\mathrm{day}^{-1}\right)$, according classification of Gonçalves et al. (2013) measures in tropical systems. These coefficients showed lower values compared to temperate (Abelho, 2001) and other tropical streams (Dobson et al., 2003; Gonçalves et
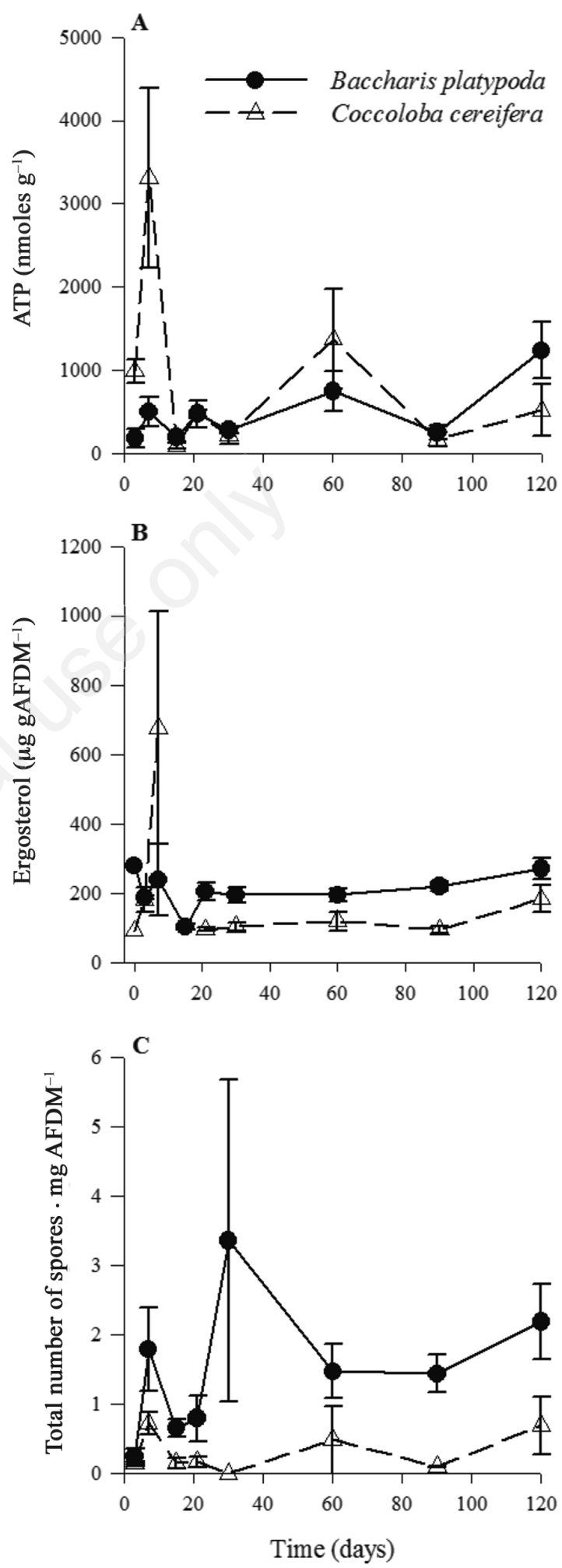

Fig. 3. Contributions of microorganisms in the detritus of Baccharis platypoda and Coccoloba cereifera during the leaf breakdown in Geraldinho Stream. A) Concentration of ergosterol (mean and standard error); B) total number of spores of aquatic hyphomycetes (mean and standard error); C) concentration of ATP (mean and standard error). 
al., 2006a; Moretti et al., 2007). Leaching occurs throughout the decomposition process (Gessner et al., 1999); however, in the present study, the reductions in total polyphenols and condensed tannins occurred slowly, particularly during the first month of incubation, due to the hardness of the leaves, which protects against water loss (Edwards et al., 2000). However, these results are inconsistent with several studies in tropical streams (Albariño and Balseiro, 2002; Schlickeisen et al., 2003; Ardón and Pringle, 2008), although they agree with the studies of Gonçalves et al. (2012a, 2012b) on native detritus in Brazilian savanna streams.

The slow leaching and decomposition rates observed in the present study may also reflect the high concentrations of lignin and cellulose in the species studied (Gessner et al., 1999). According to Hoorens et al. (2003), the initial chemical composition of the litter strongly influences decomposition, with high concentrations of structural and secondary compounds limiting this process (Ostrofsky, 1997). In addition, according to a review by Gimenes et al. (2010), tropical species have low palatability and nutritional quality and larger quantities of secondary metabolites and recalcitrant compounds than non-tropical species due to the higher herbivory pressures suffered during their evolution (Graça and Cressa, 2010). The high lignin content of $B$. platypoda, C. cereifera and other Brazilian Cerrado (=savanna) and high-altitude plants might be a consequence of the nutrient-poor and water-deficient soils of this biome (Ribeiro et al., 1999).
This scenario could explain the slow breakdown rates observed in the present study and in other tropical Cerrado streams (Gonçalves et al., 2006b; Gonçalves et al., 2007; Moretti et al., 2007; Ligeiro et al., 2010). Moreover, lignin is processed more slowly than other compounds, and its percentage increased in both species throughout the study, indicating either the accumulation of this refractory material or the preferential utilization of other, less refractile compounds. Suberkropp et al. (1976) found an increase in the percentage of lignin throughout their experiment and ascribed it to the formation of protein and phenolic compound complexes, which are very resistant and stable. These complexes behaved similarly to lignin in their analyses, giving the impression of lignin synthesis during processing.

The concentrations of structural and secondary compounds in the litter of the two species studied here are higher than those reported for other species (Ardón et al., 2006; Gonçalves et al., 2006a; Ferreira et al., 2012; Bruder et al., 2014). Silva et al. (2013) studied the cellulose, lignin and isotopic composition of 15 dominant species in the bogs in Serra do Espinhaço, southern Brazil, which are comprised primarily of moist grassland and semideciduous forest. They found that lignin content ranged from 4.3 to $19.4 \%$ and that cellulose content ranged from 3.6 to $19.5 \%$. Among 15 species of the riparian zone of Cerrado, wide variation in the initial concentrations of lignin (17.6 to $63.3 \%$ ), cellulose (15.8 to $34.6 \%$ ) and total polyphenols ( 7.7 to $36.3 \%$ ) has been ob-

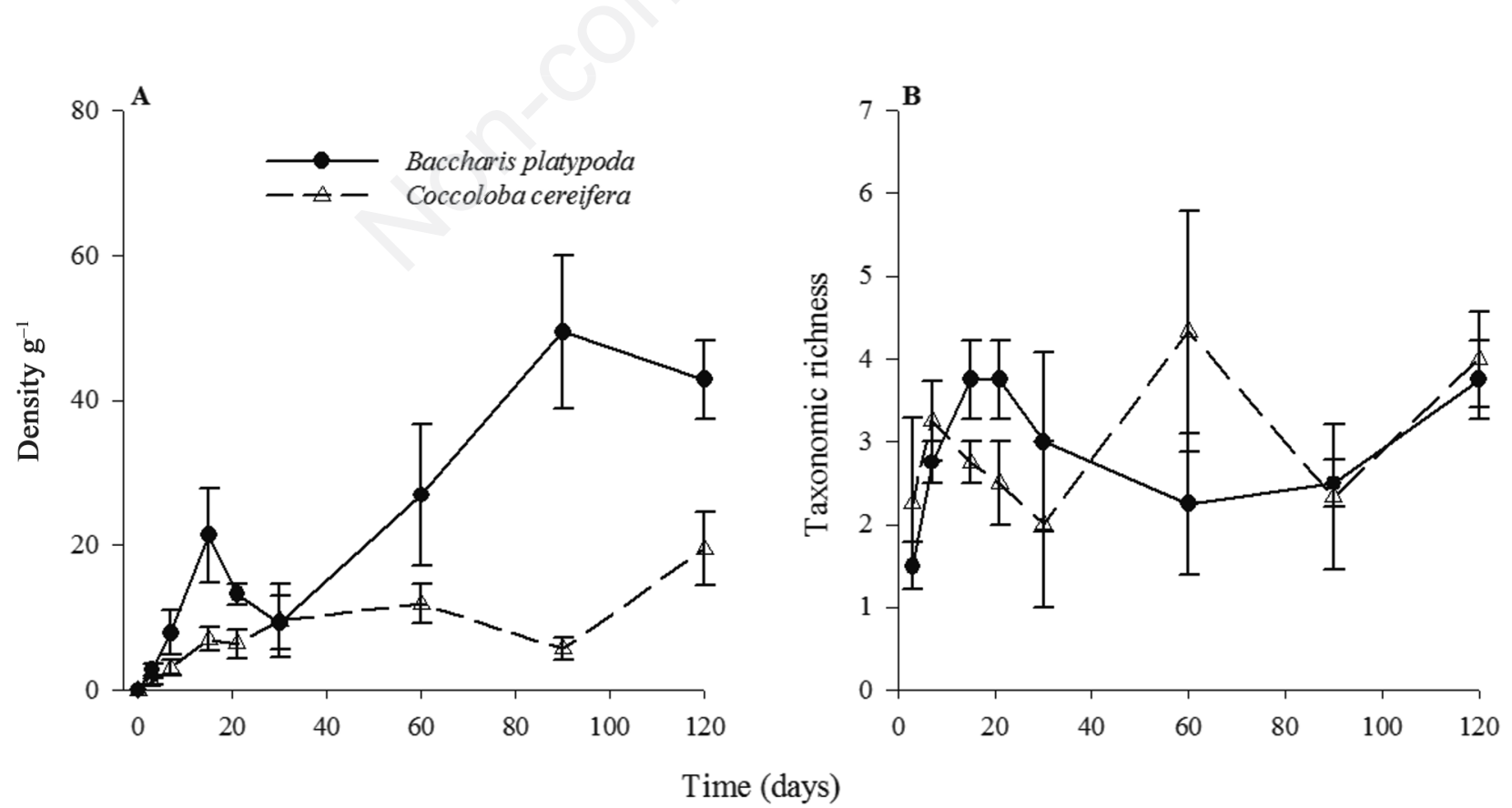

Fig. 4. Contributions of invertebrates associated with litters of Baccharis platypoda and Coccoloba cereifera during leaf breakdown in Geraldinho Stream. A)Total density (mean and standard error); B) taxonomic richness (mean and standard error). 


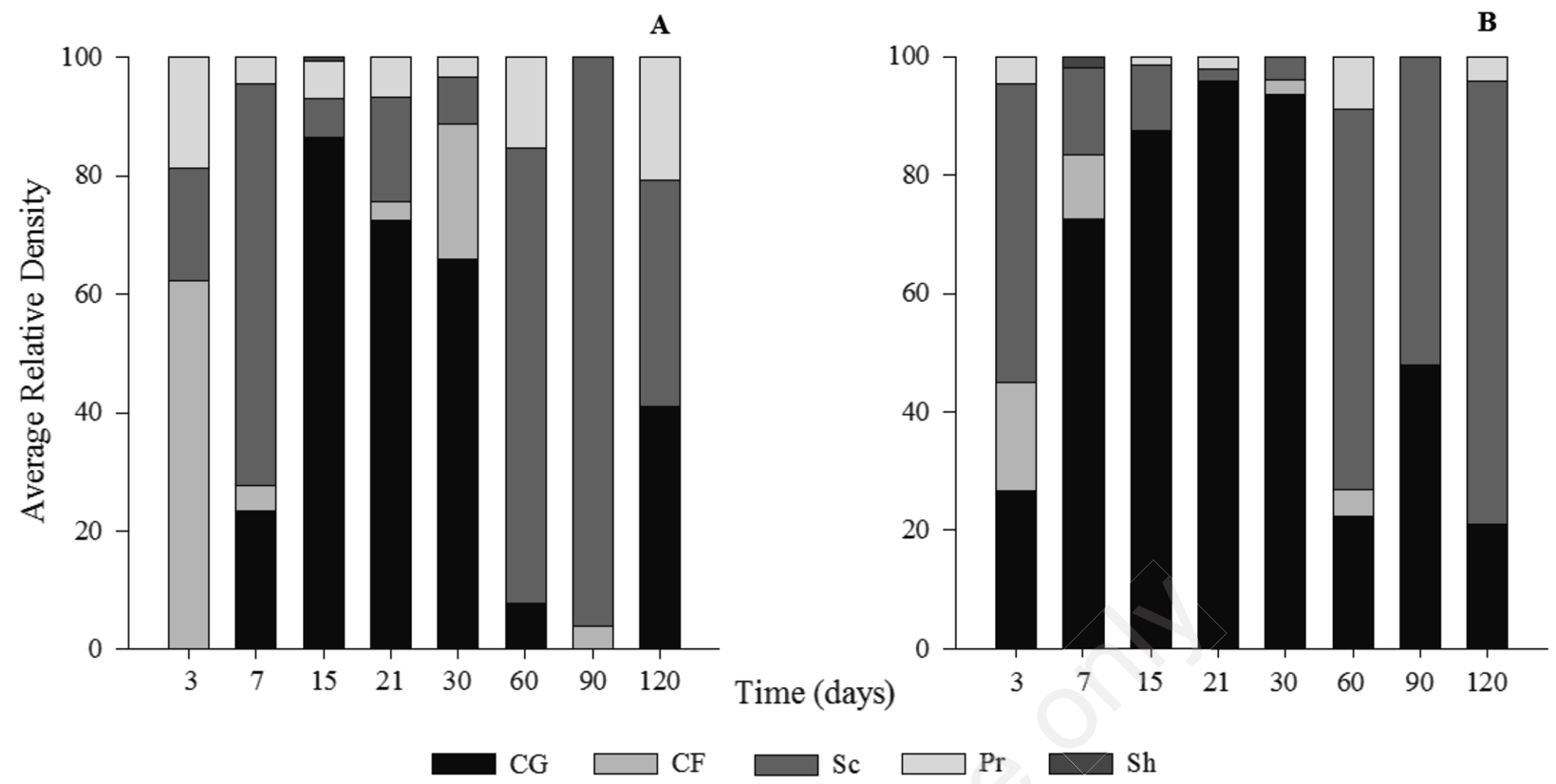

Fig. 5. Average relative densities of the functional trophic groups of the invertebrate communities associated with litters of Baccharis platypoda (A) and Coccoloba cereifera (B) during the decomposition process in Geraldinho stream. CG, collector-gatherer; CF, collector-filterer; Sc, scrapper; Pr, predator; Sh, shredder.

Tab. 2. Degrees of freedom, residuals deviance, degrees of freedom residuals, F-test statistic and P-value results of PerMANOVA (A) evaluating the main effects of litter type, incubation time and their interaction, considering five trophic functional groups of the invertebrate community (Collector-Gatherer, Collector-Filterer, Grazer-Scrapper, Predator and Shredder) and the Generalized Linear Models (GLM; B) evaluating whether the densities of the functional trophic groups were affected by species, incubation times or their interaction.

\begin{tabular}{|c|c|c|c|c|c|c|c|}
\hline Response variable & $\begin{array}{l}\text { Explanatory } \\
\text { variable }\end{array}$ & DF & Deviance & Residual DF & $\begin{array}{l}\text { Residual } \\
\text { deviance }\end{array}$ & F & $P$ \\
\hline A - PerMANOVA FFG & $\begin{array}{l}\text { Detritus } \\
\text { Time } \\
\text { Detritus x time }\end{array}$ & $\begin{array}{l}1 \\
7 \\
7\end{array}$ & & & & $\begin{array}{l}6.7 \\
4.9 \\
1.6\end{array}$ & $\begin{array}{c}<0.001 \\
<0.001 \\
0.03\end{array}$ \\
\hline B - GLM Collector-Gatherer & $\begin{array}{l}\text { Null model } \\
\text { Detritus } \\
\text { Time } \\
\text { Detritus x time }\end{array}$ & $\begin{array}{l}1 \\
7 \\
7\end{array}$ & $\begin{array}{c}64.4 \\
472.1 \\
56 \\
\end{array}$ & $\begin{array}{l}52 \\
51 \\
44 \\
37\end{array}$ & $\begin{array}{l}766.7 \\
702.3 \\
230.2 \\
174.2\end{array}$ & $\begin{array}{c}13.7 \\
14.3 \\
1.7 \\
\end{array}$ & $\begin{array}{c}<0.001 \\
<0.001 \\
0.139\end{array}$ \\
\hline Collector-Filterer & $\begin{array}{l}\text { Null model } \\
\text { Detritus } \\
\text { Time } \\
\text { Detritus x time }\end{array}$ & $\begin{array}{l}1 \\
7 \\
7\end{array}$ & $\begin{array}{c}0.05 \\
19.4 \\
0.7\end{array}$ & $\begin{array}{l}52 \\
51 \\
44 \\
37\end{array}$ & $\begin{array}{l}55.9 \\
55.8 \\
36.5 \\
26.7\end{array}$ & $\begin{array}{c}0.07 \\
3.8 \\
1.9\end{array}$ & $\begin{array}{l}0.789 \\
0.003 \\
0.092\end{array}$ \\
\hline Scrapper & $\begin{array}{l}\text { Null model } \\
\text { Detritus } \\
\text { Time } \\
\text { Detritus x time }\end{array}$ & $\begin{array}{l}1 \\
7 \\
7\end{array}$ & $\begin{array}{c}35.2 \\
446.8 \\
82.03\end{array}$ & $\begin{array}{l}52 \\
51 \\
44 \\
37\end{array}$ & $\begin{array}{c}740.2 \\
705.07 \\
258.3 \\
176.2\end{array}$ & $\begin{array}{c}7.4 \\
13.4 \\
2.4 \\
\end{array}$ & $\begin{array}{c}0.009 \\
<0.001 \\
0.035\end{array}$ \\
\hline Predator & $\begin{array}{l}\text { Null model } \\
\text { Detritus } \\
\text { Time } \\
\text { Detritus x time }\end{array}$ & $\begin{array}{l}1 \\
7 \\
7\end{array}$ & $\begin{array}{c}5.02 \\
15.3 \\
3.4\end{array}$ & $\begin{array}{l}52 \\
51 \\
44 \\
37\end{array}$ & $\begin{array}{l}74.3 \\
69.2 \\
53.9 \\
50.5\end{array}$ & $\begin{array}{l}3.6 \\
1.6 \\
0.4\end{array}$ & $\begin{array}{l}0.063 \\
0.166 \\
0.919\end{array}$ \\
\hline Shredder & $\begin{array}{l}\text { Null model } \\
\text { Detritus } \\
\text { Time } \\
\text { Detritus x time }\end{array}$ & $\begin{array}{l}1 \\
7 \\
7\end{array}$ & $\begin{array}{c}0.006 \\
0.08 \\
0.04\end{array}$ & $\begin{array}{l}52 \\
51 \\
44 \\
37\end{array}$ & $\begin{array}{c}0.6 \\
0.57 \\
0.49 \\
0.44\end{array}$ & $\begin{array}{c}0.5 \\
1.04 \\
0.6\end{array}$ & $\begin{array}{l}0.471 \\
0.416 \\
0.777\end{array}$ \\
\hline
\end{tabular}

DF, degrees of freedom. 
served (P.P. Gomes, Universidade de Brasília, personal communication). Moreover, the leaves of $C$. cereifera exhibit a thick silver waxy layer on the lamina, which is an efficient barrier to water-soluble cell compounds and impedes the entrance of hydrophilic substances.

Therefore, our results indicate that despite the higher loss in mass in B. platypoda than in C. cereifera (main effect), the similar structural and secondary compounds in the two detritus types are responsible for the similar low coefficients of decomposition over time (species-by-time interaction). The $B$. platypoda detritus had lower lignin concentrations, explaining its higher decomposition rate compare to that of $C$. cereifera, which was low. This result indicates that intrinsic factors most strongly influence decomposition rates, supporting our first hypothesis. Thus, species with higher concentrations of structural compounds delay the remobilization of energy and nutrients into the aquatic ecosystem. However, this delay could potentially improve the efficiency of the ecosystem, considering the additional primary production of biofilm in open headwater streams. We need specific experiments to show detail of this in functioning of the ecosystem.

\section{Microorganisms community}

ATP content can reflect not only the fungal biomass but also the entire set of microbes colonizing leaves. It increased with no corresponding increase in ergosterol, indicates that microorganisms other than fungi are accumulating biomass in the decomposing leaves (Gonçalves et al., 2006b; Gonçalves et al., 2007). During our experiment, peaks in ATP content were observed on days 60 and 120, while the concentration of ergosterol remained stable. This result is consistent with our hypothesis that fungal biomass can integrate with biofilm, improving overall productivity during the final stage of the decomposition in hard leaves. Moreover, the observed ATP levels might be due the colonization of algae (i.e., the formation of biofilm) during the initial stage, hiding leaf breakdown by increase of the primary production. In contrast, the fungal community is more important in the degradation of more complex compounds, particularly during the more advanced stages (Gonçalves et al., 2006a). However, slow leaching associated with low water nutrient concentrations and low palatability and nutritional quality of the detritus could negatively influence fungal colonization and consequently retard the decomposition process (Gessner and Chauvet, 1994; Quinn et al., 2000), consistent with our second hypothesis.

Plants produce a large and diverse array of organic compounds. Secondary metabolites are produced and secreted by cells following biochemical processes that involve the primary chemical compounds of the plant, and these compounds have different ecological functions, such as allelopathy or defense against herbivory (Swain, 1977).
Secondary metabolites have a much more restricted distribution than primary metabolites within the plant kingdom, and high concentrations might increase plant resistance to herbivory and insect pathogens (Mazid et al., 2011). Furthermore, in aquatic environments, secondary metabolites can accelerate or retard the decomposition process. In a laboratory study, Canhoto and Graça (1999) showed that secondary compounds decreased fungal biomass on leaves. In contrast, Ardón and Pringle (2008) suggested that secondary compounds in leaves might not persist long enough to limit microbial or insect damage because of the rapid leaching of total phenolics, condensed tannins and hydrolyzable tannins. Indeed, their results indicate that structural compounds are important in determining fungal and bacterial biomasses during leaf breakdown, supporting our results.

We observed the largest fungal biomass in both species after 90 days of incubation, suggesting that the litter presented favourable conditions for fungal colonization after this period and supporting the idea that a long period of leaching can influence the fungal community (Suberkropp et al., 1976). This result suggests that leaf breakdown in this stream is delayed, as leaching persisted until the end of the experiment and conditioning appeared to begin after 90 days. This increase in fungal biomass during the late decomposition stage is typical of refractory leaf species, in which colonization is slow (Gonçalves et al., 2006b; Encalada et al., 2010). The present study provides the first record of a long leaching period in a tropical stream: we observed almost no decomposition of high structural and secondary compounds over the first 60 days, indicating the level of detritus quality. Moreover, the first stages of decomposition proceeded slowly, yielding substrate for the accumulation of biofilm. This pattern might prepare the detritus for fungal activity during the final stage of leaf breakdown, facilitating the absorption of nutrients and energy accumulation in the biofilm, at which point the rate of decomposition might accelerate.

The circumneutral stream water and high dissolved oxygen content may enhance fungal sporulation (Medeiros et al., 2009). However, low water flow and the associated low nutrient availability in the water and leaf substrate (Ferreira et al., 2006) proved to be most prevalent factors that can negatively affect the sporulation rates of aquatic hyphomycetes (Suberkropp, 1998). These features may explain the lower sporulation rate in the present study relative to other studies (Hieber and Gessner, 2002; Ferreira et al., 2006). Thus, low nutrient concentrations of the stream associated with the presence of endemic leaves that are nutrient-poor and abundant in riparian vegetation lead to low breakdown rates in aquatic systems. In this study, high concentrations of secondary compounds of detritus affected the community of aquatic hyphomycetes; however, at the end of the experiment, when 
approximately $80 \%$ of the original mass remained, spore numbers were beginning to increase, indicating an increase in the reproductive activity of this group.

\section{Invertebrate colonization}

The low dissolved nutrient content in water and the delay in the leaf conditioning process may also have been responsible for the low densities and richness of invertebrates observed in the present study. These results demonstrate the importance of environmental conditions and microorganisms in the nutritional quality of the leaf litter, increasing its palatability to invertebrate shredders (Gonçalves et al., 2007; Moretti et al., 2007; Moulton et al., 2010), in support of our second hypothesis. Baccharis platypoda had higher invertebrate density and richness values and often higher ergosterol concentrations than $C$. cereifera. Higher densities of invertebrates were recorded at later sampling dates, coinciding with the peak concentration of ergosterol. In a tropical stream, Ligeiro et al. (2010) also found higher values of invertebrate richness, biomass and density at the last sampling dates and suggested that the litter that was still in the intermediate stages of decomposition presented larger quantities of resources for the associated invertebrates. As shredders prefer conditioned leaves, tougher leaves, such as those of $C$. cereifera, might break down more slowly due to reduced microbial activity and shredder feeding. Therefore, the attractiveness of a certain type of detritus to invertebrates depends on the chemical composition, stage of microbial colonization and exposure time of the detritus.

Chironomidae and Baetidae were the predominant groups of invertebrates present during the entire decomposition process, as observed in studies of tropical streams (Mathuriau and Chauvet, 2002; Moulton and Magalhães, 2003; Gonçalves et al., 2006a). According to Gonçalves et al. (2006a), these two groups could be responsible for structuring the invertebrate community due to their strong colonization capacities, regardless of litter quality or the stage of decomposition. Litter species with low decomposition rates may be more important as substrates for the fixation of invertebrates and may eventually become the source of fine particles (Ardón and Pringle, 2008). In the present study, both B. platypoda and C. cereifera decomposed slowly. Given their long residence time in the stream, they might serve as permanent substrates for the development of several aquatic invertebrates, such as Chironomidae larvae, which have a larval phase of 26 days (Ramírez and Pringle, 2006).

The functional feeding group of collector-gatherer had the highest densities in either detritus type, followed by scrapers. Members of this group feed on fine particulate organic matter and do not participate directly in the decomposition process, thus suggesting a continuous accumulation of fine particulate organic matter in the litter bags (Mathuriau and Chauvet, 2002). The distribution of scrapers is likely influenced by the growth of biofilm on the litter surface, which in turn may be related to the colonization and activity of microorganisms, highlighting the importance of biofilm to the food chain and nutrient cycling in lotic systems (Dobson et al., 2002; Gonçalves et al., 2007; Li et al., 2009). This result supports our hypothesis because the abundance of this group indicates rapid development of biofilm in the detritus studied. However, the relative abundance of collector-filterer, predator and shredder groups did not vary over the decomposition process, suggesting that detritus is used only as substrate in these groups. Moreover, as we did not reach $1 / 4$ of the total decomposition of leaves of either species, these organisms may have not yet encountered the conditions favoring high activity in the detritus food web.

Shredders directly utilize the organic matter in leaf tissue for feeding, transforming it into smaller particles for fragmentation (Graça, 2001), but the importance of this group in leaf breakdown in tropical streams is unclear. Their low abundance in these environments may be due to the higher temperatures of tropical streams relative to temperate ones (Yule et al., 2009) or the existence of strong competitive interactions once resources (i.e., the amount and quality of leaf litter inputs) are limited (Boyero et al., 2012). Our results show that the invertebrate community was not responsible for the changes in leaf breakdown, consistent with studies in tropical streams (Gonçalves et al., 2007; Moretti et al., 2007). Some studies show that shredders have low abundance in tropical streams and emphasize the importance of microorganisms as major regulators of the process (Dobson et al., 2002; Gonçalves et al. 2007, Li et al., 2009; Boyero et al., 2012; Bruder et al., 2014). However, the opposite pattern has been identified in streams of temperate and subtropical zones and in high-altitude streams in the tropics, suggesting a greater importance of shredders (Graça, 2001; Yule et al., 2009; Encalada et al., 2010; Ferreira et al., 2012; König et al., 2014). Moreover, most studies have measured abundance or density, but the relative importance of this group should be assessed by biomass, as demonstrated by Tonin et al. (2014).

\section{CONCLUSIONS}

Headwater tropical streams have chemically diverse detrital resources. We found that intrinsic components of litter (specifically, the high concentrations of secondary and structural compounds) have the potential to play key roles in the decomposition process, supporting our first hypothesis. These high concentrations hinder microbial colonization and thereby both affect the composition and structure of the associated invertebrate community and slow leaf breakdown, supporting our second hypothesis. The low palatability and nutritional quality of detritus, 
which are associated with the dissolved nutrient concentrations in water, delay the conditioning process in the leaves. This slows the participation of microbial and invertebrate communities, leading to major physical decomposition. Low decomposition species are important to the invertebrate community as substrates and as sources of particulate organic matter; i.e., as food resources. Our results increase our understanding of the decomposition process and associated interactions in these litters and broaden our knowledge of the ecological processes in high-altitude lotic ecosystems. We speculate that a key determining factor of the decomposition process was the long leaching duration (60 days) of the tropical stream, which delayed the conditioning process for 90 days. Future perspective studies are needed that assess the relationships among fungi, biofilm and ecosystem productivity in natural open streams. Our results suggest that these factors may have strong effects on the detritus-primary productive food web in this ecosystem. We tested part of this hypothesis in the present study and provide the first evidence of the complex structure of this ecosystem.

\section{ACKNOWLEDGMENTS}

We thank the members of the UFMG Benthos Ecology Laboratory for help in the field and laboratory. The first author received a scholarship from CNPq during her Master's research. This research was financial supported by FAPEMIG/PRONEX (Edital 20/2006; proc. 465/07) through the project Ecological and Climatic Dimensions of Biodiversity in Baccharis: from molecules to organisms coordinated by Dr. G.W. Fernandes.

\section{REFERENCES}

Abelho M, 2001. From litterfall to breakdown in streams: a review. Sci. World J. 1:658-680.

Abelho M, 2005. Extraction and quantification of ATP as a measure of microbial biomass, p. 223-229. In: M.A.S. Graça, F. Bärlocher and M.O. Gessner (eds.), Methods to study litter decomposition: a practical guide. Springer.

Albariño RJ, Balseiro EG, 2002. Leaf litter breakdown in Patagonian streams: native versus exotic trees and the effect of invertebrate size. Aquat. Conserv. 12:181-192.

APHA, 2005. Standard methods for the examination of water and wastewater, $18^{\text {th }}$ ed. American Public Health Association, Washington.

Ardón M, Pringle CM, 2008. Do secondary compounds inhibit microbial- and insect-mediated leaf breakdown in a tropical rainforest stream, Costa Rica? Oecologia 155:311-323.

Ardón M, Stallcup LA, Pringle CM, 2006. Does leaf quality mediate the stimulation of leaf breakdown by phosphorus in Neotropical streams? Freshwater Biol. 51:618-633.

Bärlocher F, 2005. Sporulation by aquatic Hyphomycetes, p. 185-187. In: M.A.S. Graça, F. Bärlocher and M.O. Gessner (eds.), Methods to study litter decomposition: a practical guide. Springer.

Bärlocher F, Graca MAS, 2005. Total phenolics, p. 97-100. In:
M.A.S. Graça, F. Bärlocher and M.O. Gessner (eds.), Methods to study litter decomposition: a practical guide. Springer.

Boyero L, Pearson RG, Dudgeon D, Ferreira V, Graça MAS, Gessner MO, Boulton AJ, Chauvet E, Yule CM, Albariño RJ, Ramirez A, Helson J, Callisto M, Arunachalam M, Chara J, Figueroa R, Mathooko J, Gonçalves JF, Moretti M, Chara AM, 2012. Global patterns of stream detritivore distribution: implications for biodiversity loss in changing climates. Glob. Ecol. Biogeogr. 21:134-141.

Bruder A, Schindler MH, Moretti MS, Gessner MO, 2014. Litter decomposition in a temperate and a tropical stream: the effects of species mixing, litter quality and shredders. Freshwater Biol. 59:438-449.

Canhoto C, Graça MAS, 1999. Leaf barriers to fungal colonization and shredders (Tipula lateralis) consumption of decomposing Eucalyptus globules. Microb. Ecol. 37:163-172.

Carmouze JP, 1994. [O metabolismo dos ecossistemas aquáticos: fundamentos teóricos, métodos de estudo e análises químicas].[Book in Portuguese]. Edgard Blücher / FAPESP: $254 \mathrm{pp}$

Chara J, Baird D, Telfer T, Giraldo L, 2007. A comparative study of leaf breakdown of three native tree species in a slowlyflowing headwater stream in the Colombian Andes. Int. Rev. Hydrobiol. 92:183-198.

Cummins KW, Merrit RW, Andrade PCN, 2005. The use of invertebrate functional groups to characterize ecosystem attributes in selected streams and rivers in south Brazil. Stud. Neotrop. Fauna Environ. 40:69-89.

Cummins KW, Wilzbach MA, Gates DM, Perry JB, Talaiferro WB, 1989. Shredders and riparian vegetation. BioScience 39:24-30.

Das M, Royer TV, Leff LG, 2008. Fungal communities on decaying leaves in streams: a comparison of two leaf species. Mycol. Prog. 7:267-275.

Dobson M, Magana A, Mathooko JM, Ndegwa FK, 2002. Detritivores in Kenyan highland streams: more evidence for the paucity of shredders in the tropics? Freshwater Biol. 47:909-919.

Dobson M, Mathooko JM, Ndegwa FK, M'Erimba C, 2003. Leaf litter processing rates in a Kenyan highland stream, the Njoro River. Hydrobiologia 519:207-210.

Edwards C, Read J, Sanson G, 2000. Characterising sclerophylly: some mechanical properties of leaves from heath and forest. Oecologia 123:158-167.

Encalada AC, Calles J, Ferreira V, Canhoto CM, Graça MAS, 2010. Riparian land use and the relationship between the benthos and litter decomposition in tropical montane streams. Freshwater Biol. 55:1719-1733.

Ferreira V, Encalada AC, Graça MAS, 2012. Effects of litter diversity on decomposition and biological colonization of submerged litter in temperate and tropical streams. Freshwater Sci. 31:945-962.

Ferreira V, Gulis V, Graça MAS, 2006. Whole-stream nitrate addition affects litter decomposition and associated fungi but not invertebrates. Oecologia 149:718-729.

Flindt MR, Lillebø AI, 2005. Determination of total nitrogen and phosphorus in leaf litter, p. 53-61. In: M.A.S. Graça, F. Bärlocher and M.O. Gessner (eds.), Methods to study litter decomposition: a practical guide. Springer.

Gessner MO, 2005a. Proximate lignine and cellulose, p. 115- 
120. In: M.A.S. Graça, F. Bärlocher and M.O. Gessner (eds.), Methods to study litter decomposition: a practical guide. Springer.

Gessner MO, 2005b. Ergosterol as a measure of fungal biomass, p. 189-195. In: M.A.S. Graça, F. Bärlocher and M.O. Gessner (eds.), Methods to study litter decomposition: a practical guide. Springer.

Gessner MO, Chauvet E, 1994. Importance of stream microfungi in controlling breakdownrates of leaf litter. Ecology 75:1807-1817.

Gessner MO, Chauvet E, Dobson M, 1999. A perspective on leaf litter breakdown in streams. Oikos 85:377-384.

Gimenes KZ, Cunha-Santino MB, Bianchini Jr I, 2010. [Decomposição de matéria orgânica alóctone e autóctone em ecossistemas aquáticos].[Article in Portuguese]. Oecologia Aust. 14:1036-1073.

Gonçalves JF Jr, França JS, Medeiros AO, Rosa CA, Callisto M, 2006a. Leaf Breakdown in a Tropical Stream. Int. Rev. Hydrobiol. 91:164-177.

Gonçalves JF Jr, Graça MAS, Callisto M, 2006b. Leaf-litter breakdown in 3 streams in temperate, Mediterranean, and tropical Cerrado climates. J. N. Am. Benthol. Soc. 25:344-355.

Gonçalves JF Jr, Graça MAS, Callisto M, 2007. Litter decomposition in a Cerrado savannah stream is retarded by leaf toughness, low dissolved nutrients and a low density of shredders. Freshwater Biol. 52:1440-1451.

Gonçalves JF Jr, Martins RT, Ottoni BMP, Couceiro SEM, 2013. [Uma visão sobre a decomposição foliar em sistemas aquáticos brasileiros, p. 89-116.]. In: N. Hamada, J.L. Nessimian and R.B. Querino (eds.) [Insetos Aquáticos na Amazônia brasileira: taxonomia, biologia e ecologia].[Book in Portuguese]. Editora do INPA.

Gonçalves JF Jr, Rezende RS, Franca J, Callisto M, 2012a. Invertebrate colonisation during leaf processing of native, exotic and artificial detritus in a tropical stream. Mar. Freshw. Res. 63:428-439.

Gonçalves JF Jr, Rezende RS, Martins NM, Gregório RS, 2012b. Leaf breakdown in an Atlantic Rain Forest stream. Austral Ecol. 37:807-815.

Graça MAS, 2001. The role of invertebrates on leaf litter decomposition in stream - a review. Int. Rev. Hydrobiol. 86:383-393.

Graça MAS, Bärlocher F, 2005. Radial diffusion assay for tannins, p. 101-108. In: M.A.S. Graça, F. Bärlocher and M.O. Gessner (eds.), Methods to study litter decomposition: a practical guide. Springer.

Graça MAS, Cressa C, 2010. Leaf quality of some tropical and temperate tree species as food resource for stream shredders. Int. Rev. Hydrobiol. 95:27-41.

Hieber M, Gessner MO, 2002. Contribution of stream detrivores, fungi and bacteria to leaf breakdown based on biomass estimates. Ecology 83:1026-1038.

Hoorens B, Aerts R, Stroetenga M, 2003. Does initial litter chemistry explain litter mixture effects on decomposition? Oecologia 137:578-586.

König R, Santos S, Hepp LU, 2014. Colonisation of low- and high-quality detritus by benthic macroinvertebrates during leaf breakdown in a subtropical stream. Limnologica 45: 61-68.

Li AOY, Lily CY, Dudgeon D, 2009. Effects of leaf toughness and nitrogen content on litter breakdown and macroinvertebrates in a tropical stream. Aquat. Sci. 71:80-93.

Ligeiro R, Moretti MS, Gonçalves JF Jr, Callisto M, 2010. What is more important for invertebrate colonization in a stream with low-quality litter inputs: exposure time or leaf species? Hydrobiologia 654:125-136.

Mathuriau C, Chauvet R, 2002. Breakdown of leaf litter in a neotropical stream. J. N. Am. Benthol. Soc. 21:384-396.

Mazid M, Khan TA, Mohammad F, 2011. Role of secondary metabolites in defense mechanisms of plants. Biol. Med. 3:232-249.

Medeiros AO, Pascoal C, Graça MAS, 2009. Diversity and activity of aquatic fungi under low oxygen conditions. Freshwater Biol. 54:142-149.

Merrit RW, Cummins KW, 1996. An introduction to the aquatic insects of North America. Kendall/Hunt: 862 pp.

Moretti M, Gonçalves JF Jr, Callisto M, 2007. Leaf breakdown in two tropical streams: Differences between single and mixed species packs. Limnologica 37:250-258.

Moulton TP, Magalhães SAP, 2003. Responses of leaf processing to impact in streams in atlantic rain forest, Rio de Janeiro, Brazil - A test of the biodiversity ecosystem functioning relationship? Braz. J. Biol. 63:87-95.

Moulton TP, Magalhães-Fraga SAP, Brito EF, Barbosa FA, 2010. Macroconsumers are more important than specialist macroinvertebrate shredders in leaf processing in urban forest streams of Rio de Janeiro, Brazil. Hydrobiologia 638:55-66.

Mugnai R, Nessimian JL, Baptista DF, 2009. [Manual de identificação de macroinvertebrados aquáticos do estado do Rio de Janeiro].[Book in Portuguese]. Technical Books: 176 pp.

Olson JS, 1973. Energy storage and the balance of producers and decomposers in ecological systems. Ecology 44:321331.

Ostrofsky ML, 1997. Relationship between chemical characteristics of autumn-shed leaves and aquatic processing rates. J. N. Am. Benthol. Soc. 16:750-759.

Quinn JM, Burrell GP, Parkyn SM, 2000. Influences of leaf toughness and nitrogen content on in-stream processing and nutrient uptake by litter in a Waikato, New Zealand, pasture stream and streamside channels. New Zeal. J. Mar. Fresh. 34:253-271.

Ramírez A, Pringle CM, 2006. Fast growth and turnover of chironomid assemblages in response to stream phosphorus levels in a tropical lowland landscape. Limnol. Oceanogr. 51:189-196.

Ribeiro SP, Braga AO, Silva CHL, Fernandes GW, 1999. Leaf polyphenols in Brazllian Melastomataceae: sclerophylly, habitats, and insect herbivores. Ecotropica 5:137-146.

Schlickeisen E, Tietjen TE, Arsuffi TL, Groeger AW, 2003. Detritus processing and microbial dynamics of an aquatic macrophyte and terrestrial leaf in a thermally constant, spring-fed stream. Microb. Ecol. 45:411-418.

Silva VE, Silva AC, Pereira RC, Camargo PB, Silva BPC, Barral UM, Mendonça-Filho CV, 2013. [Composição lignocelulósica e isótopica da vegetação e da matéria orgânica do solo de uma turfeira tropical: I - composição florística, fitomassa e acúmulo de carbono].[Article in Portuguese]. Rev. Bras. Cienc. Solo 37:121-133.

Suberkropp K, 1998. Effect of dissolved nutrients on two aquatic 
hyphomycetes growing on leaf litter. Mycol. Res. 102:9981002.

Suberkropp K, Godschalk GL, Klug MJ, 1976. Changes in the chemical composition of leaves during processing in a woodland stream. Ecology 57:720-727.

Swain T, 1977. Secondary compounds as protective agents. Ann. Rev. Plant Physiol. 28:479-501.

Tonin AM, Hepp LU, Restello RM, Gonçalves JF Jr, 2014. Understanding of colonization and breakdown of leaves by invertebrates in a tropical stream is enhanced by using biomass as well as count data. Hydrobiologia DOI 10.1007/s10750014-1939-9

Vannote RL, Minshall GW, Cummins KW, Sedell JR, Cushing
CE, 1980. The river continuum concept. Can. J. Fish. Aquat. Sci. 37:130-137.

Wallace JB, Eggert SL, 2009. Benthic invertebrate fauna, small streams. Encycl. Inland Waters 2:173-190.

Wantzen KM, Rosa FR, Neves CO, Nunes da Cunha C, 2005. Leaf litter addition experiments in riparian ponds with different connectivity to a Cerrado stream in Mato Grosso, Brazil. Amazoniana 18:387-396.

Yule CM, Leong MY, Liew KC, Ratnarajah L, Schmidt K, Wong HM, Pearson RG, Boyero L, 2009. Shredders in Malaysia: abundance and richness are higher in cool upland tropical streams. J. N. Am. Benthol. Soc. 28:404-415. 